\title{
Acute Cocaine-Induced Seizures: Differential Sensitivity of Six Inbred Mouse Strains
}

\author{
G. T. Golden, Ph.D., T. N. Ferraro, Ph.D., G. G. Smith, B.S., R. L. Snyder, M.S., N. L. Jones, B.S., \\ and W. H. Berrettini, M.D., Ph.D.
}

Mature male and female mice from six inbred stains were tested for susceptibility to behavioral seizures induced by a single injection of cocaine. Cocaine was injected ip over a range of doses (50-100 $\mathrm{mg} / \mathrm{kg}$ ) and behavior was monitored for 20 minutes. Seizure end points included latency to forelimb or hindlimb clonus, latency to clonic running seizure and latency to jumping bouncing seizure. A range of strain specific sensitivities was documented with $A / J$ and SJL mice being most sensitive and C57BL/6J most resistant. $D B A / 2 J, B A L B / c B y J$ and NZW/LacJ strains exhibited intermediate sensitivity. EEG recordings were made in $S J L$, $A / J$ and $C 57 B L / 6 J$ mice revealing a close correspondence between electrical activity and behavior. Additionally, levels of cocaine determined in hippocampus and cortex were not different between sensitive and resistant strains. Additional studies of these murine strains may be useful for investigating genetic influences on cocaine-induced seizures. [Neuropsychopharmacology 24:291-299, 2001] (C) 2001 American College of Neuropsychopharmacology. Published by Elsevier Science Inc.

1991; Leppert et al. 1991; Weissbecker et al. 1991; Greenberg et al. 1992).

Cocaine abuse is associated with multiple forms of toxicity and seizures represent a major source of cocaine-induced fatalities (Jonosson et al. 1983; Myers and Earnest 1984; Alldredge, Lowenstein et al. 1989; Choy-Kwong and Lipton 1989; Ernst and Sanders 1989; Ogunyemi et al. 1989; Schwartz 1989; Derlet and Albertson 1989a, 1989b; Dhuna and Pascual-Leone 1990; Dhuna et al. 1991; Holland et al. 1992; Tseng et al. 1992) with eleven percent of substance abusers reporting seizures related to cocaine use (Washton and Tatarsky 1983). As the number of users of cocaine in the U.S.A. exceeds 1.5 million (Park 1997) it can be estimated that approximately 100,000 individuals have experienced cocaine-induced seizures.

The present study represents a systematic strain investigation of acute cocaine-induced seizure sensitivity, a complex trait having genetic and environmental influences. By testing a number of mouse inbred strains for susceptibility to acute cocaine-induced seizures, this study lays the foundation for genetic mapping of specific genes involved in the expression of this complex trait. Because seizure phenomena show striking parallels between mice and humans, and because extensive 
genetic homology exists between these two species, localization of genes involved in sensitivity to cocaine induced seizures will provide an inroad for studying genetic influence in human drug abuse. The results of this study identify A/J and SJL strains of mice as sensitive to the acute seizure-inducing effect of cocaine whereas C57 mice are significantly more resistant suggesting that these strains may be particularly useful for genetic dissection of this complex trait.

\section{MATERIALS AND METHODS}

\section{Animals}

Mature male and female mice from six inbred strains (The Jackson Laboratory, Bar Harbor, ME) were housed by gender (5-6/cage). All mice were housed separately in the Coatesville, VA, animal facility for a least one week prior to use. Mice were tested for susceptibility to seizures induced by an acute injection of cocaine. A total of 519 mice (C57BL/6J $\mathrm{n}=124, \mathrm{DBA} / 2 \mathrm{~J} \mathrm{n}=48$, BALB/ $\mathrm{n}=48, \mathrm{SJ} / \mathrm{L} \mathrm{n}=141, \mathrm{NZW} / \mathrm{n}=37, \mathrm{~A} / \mathrm{J} \mathrm{n}=121$ ) were tested for acute cocaine-induced seizures using ip injection of 50, 60, 70, 75, 80, 90 and $100 \mathrm{mg} / \mathrm{kg}$ of cocaine $\mathrm{HCl}$. Some strains did not receive all cocaine doses. All mice were between 7 and 11 weeks of age at the time of testing and were maintained on ad libitum food and water and a 12-hr light-dark cycle. Prior to testing, animals were placed in an isolated, air-conditioned testing room illuminated by overhead fluorescent lighting for at least 30 minutes. All testing was conducted during the light phase of the animal's light-dark cycle (9 A.M.-4 P.M.). All experiments were approved by the Coatesville VAMC Instutional Animal Care and Use Committee.

\section{Seizure Testing}

Separate groups ( $\mathrm{n}=8-31 /$ group) of individually housed male and female mice were injected with cocaine. Immediately following injection, mice were placed in individual plexiglass observation chambers (width: $15 \mathrm{~cm}$; length: $20 \mathrm{~cm}$; height: $30 \mathrm{~cm}$ ) with a wire mesh floor and observed for 20 minutes, during which time behavioral seizure measures were recorded. Cocaine was administered as the hydrochloride salt in physiological saline ( $\mathrm{pH}$ 6.1), injection concentration 6.0 $\mathrm{mg} / \mathrm{ml}$. Behavior was monitored for 20 minutes after the administration of cocaine. Latency to onset of behavioral seizure activity and number and type of behavioral seizures during the 20-min observation period were recorded by two observers with inter-rater reliability established in previous studies on kainate-induced seizure phenotypes in these and other strains (Golden et al. 1991, 1994, 1995; Ferraro et al. 1995a, 1995b, 1997). In contrast to other pharmacological seizure inducing agents, cocaine typically produces a much sharper tran- sition from non-convulsive behavior to generalized convulsions with little indication of intermediate forms such as myoclonic jerks. Clonic seizure activity is the most common expression of both acute cocaine-induced seizures as well as cocaine-kindled seizures (Marley et al. 1991a). In this study, a cocaine-induced seizure was defined as the occurrence of clonic seizure activity characterized by rapid rhythmic contraction and relaxation of muscles in extremities or as episodes of violent and dramatic uninhibited running and jumping/bouncing. Although this definition of seizures includes different behaviors, these behaviors represent the natural progression of behavioral seizure severity seen in mice in response to an acute cocaine injection.

In addition to monitoring the number of mice from each strain exhibiting seizures, latency from time of cocaine injection to initiation of seizure activity was monitored and used to generate a single quantitative measure of seizure susceptibility for each animal (seizure severity score). The seizure severity score was generated by using the following weighted formula based on latencies to the three different components of seizure phenotype:

Score $=[\text { (latency to forelimb or hindlimb clonus })^{-1} \times$ $1000 \times 0.2]+\left[(\text { latency to clonic running seizure })^{-1} \times\right.$ $1000 \times 0.3]+[($ latency to clonic jumping/bouncing seizure $)^{-1} \times 1000 \times 0.5$ ]

where $0.2,0.3$, and 0.5 are the weights of the components.

The seizure phenotype components occur in a consistent progression from clonus to jumping/bouncing seizures in the most seizure-sensitive animals. The total seizure severity score was calculated from the sum of each component (reciprocal of latency X 1000) times its assigned weight (higher weights given to more severe seizure components). Thus the weighted seizure severity score included measures of both seizure latency and seizure severity. A similar weighted seizure severity score was used in a recent study of kainic acid seizure susceptibility (Ferraro et al. 1997).

\section{EEG Studies}

Cocaine-induced behavioral seizure activity was confirmed by electroencephalographic (EEG) recordings. Eighteen mice (males, 8-10 weeks of age, 6/strain) from the C57, SJL and A/J strains underwent surgery for implantation of chronic EEG electrodes. Burr holes were made in the skull overlying the left and right parietoocciptal cortex and frontal sinus. Lead wires from a tripolar electrode (MS333/3 Plastics One, Roanoke, VA) were inserted under the skull. One lead was placed in contact with the cortical surface, one lead was inserted into the hippocampus and the third lead was connected to an inactive reference site in the frontal sinus. The tripolar electrode was attached to the skull with stainless steel screws and dental acrylic. Forty-eight hours following surgery, mice were injected with cocaine (70 
$\mathrm{mg} / \mathrm{kg}$, ip) and the EEG recorded and behavior observed for 45 minutes.

\section{Pharmacokinetic Studies}

To investigate the possibility that strain differences in cocaine-induced seizure susceptibility might reflect differences in brain absorption and distribution of cocaine, C57 mice $(n=10)$ and $A / J$ mice $(n=10)$ were injected with cocaine $\mathrm{HCI}(70 \mathrm{mg} / \mathrm{kg}$, ip) and killed at 2 minutes $(\mathrm{n}=$ $5 /$ strain) or 5 minutes ( $n=5 /$ strain) post injection. Quantitative brain concentrations of cocaine and the cocaine metabolite benzoylecgonine were determined in cortex and hippocampus by National Medical Services (Willow Grove, PA) using the gas chromatography-mass spectrometry method (Javaid et al. 1978; Patrick et al. 1993).

\section{Kainic Acid Seizure Studies}

A dose/response study of susceptibility to kainic acid seizures was conducted to determine if a general predisposition for seizure activity produced by pharmacologic agents is present in the mouse strains susceptible to cocaine-induced seizures. Mature C57BL/6J, DBA/2J, A/J and SJL/J mice (3-10/strain) were injected subcutaneously with kainic acid (distilled H20, pH 7.2, 2 mg/ml) at doses of $10,20,25$, or $30 \mathrm{mg} / \mathrm{kg}$ and observed for seizure activity for four hours using observation conditions identical to those described for cocaine seizure testing.

\section{Data Analysis}

Dose response data were analyzed using both parametric and nonparametric methods. Three factor [strain (6) $X$ dose (4) $X$ sex (2)] ANOVAs (continuous data) and Kruskal-Wallis/Friedman tests (ranked data) were performed for each continuous seizure measure and $X^{2}$ analyses for discrete seizure measures. Post hoc testing was conducted using the Bonferroni/Dunn multiple comparison procedure.

\section{RESULTS}

\section{Cocaine-induced Behavioral Seizures}

Seizure latencies following administration of cocaine were on the order of several minutes (range 0.58-13.98 $\mathrm{min}$ ) with the rank order of latencies (longest to shortest) being $\mathrm{C} 57>\mathrm{NZW}=\mathrm{DBA}>\mathrm{BALB}>\mathrm{SJL}=\mathrm{A} / \mathrm{J} . \mathrm{A} \mathrm{X}^{2}$ analysis for strain differences in seizure frequency using all six strains (collapsed across sex) was highly significant at cocaine doses of $60 \mathrm{mg} / \mathrm{kg}\left(X^{2}=27.1, p<.0001\right.$, Cont Coff $=.40$, Cramer's V = .44), $70 \mathrm{mg} / \mathrm{kg}$ cocaine doses $\left(\mathrm{X}^{2}=43.2, p<.0001\right.$, Cont Coff $=.45$, Cramer's V $\left.=.50\right)$ and $80 \mathrm{mg} / \mathrm{kg}\left(\mathrm{X}^{2}=11.2, p<.0003\right.$, Cont Coff $=.41$, Cramer's V $=.44)$. Sex differences in seizure sensitivity to acute cocaine injection were also detected. Within the seizure resistant C57 strain, females tended to be more susceptible to cocaine-induced seizures than males (Figure 1). Statistically significant sex differences in the C57 strain were seen at the higher cocaine doses and were revealed by both the number of animals demonstrating seizures and the weighted seizure severity score (Table 1$)$. For the more seizure susceptible strain (SJL and A/J), no sex differences in seizure susceptibility were noted, i.e., there were no statistically significant differences in weighted seizure severity score or number of mice exhibiting seizures between C57, SJL and A/J strains when females were analyzed separate from males. The $60 \mathrm{mg} / \mathrm{kg}$ cocaine dose in $\mathrm{A} / \mathrm{J}$ mice was the only exception (Table 1) where $66.7 \%$ of male and $22.2 \%$ of female $\mathrm{A} / \mathrm{J}$ 's exhibited seizures. This difference approached but did not reach statistical significance $(p=.058)$.

Figure 2 shows the mean ( \pm s.e.) weighted seizure severity scores for each strain as a function of acute cocaine dose. A 2-factor ANOVA using STRAIN (3) X DOSE (7) was highly significanxt $(p<.0001)$ for the main effects of COCAINE DOSE and STRAIN (C57, $\mathrm{SJL}, \mathrm{A} / \mathrm{J}$ ). Based on dose response seizure severity data the cocaine dose that best discriminates resistant from susceptible strains is $70-80 \mathrm{mg} / \mathrm{kg}$. The C57 strain appears to be the most resistant to cocaine-induced seizures and the $\mathrm{A} / \mathrm{J}$ and SJL strains appear to be most sensitive to acute cocaine-induced seizures.

\section{EEG Studies}

EEG recordings made from cerebral cortex and hippocampus of C57 $(\mathrm{n}=6), \mathrm{A} / \mathrm{J}(\mathrm{n}=5)$ and SJL $(\mathrm{n}=5)$ mice following acute injection of cocaine $(70 \mathrm{mg} / \mathrm{kg})$ detected electrographic seizure discharges associated with behavioral seizures in SJL mice; no electrographic seizure discharges were noted in any C57 mice. C57 mice did show ataxia and increased motor activity often associated with a synchronization of EEG activity first in hippocampus, then later in cortex (Figure 3). Electrographic seizure activity was also confirmed in $\mathrm{A} / \mathrm{J}$ mice at the $70 \mathrm{mg} / \mathrm{kg}$ dose of cocaine (not shown).

\section{Kainic Acid-induced Seizures}

A dose response study of the effects of kainic acid (KA) on seizure susceptibility in C57BL/6J, DBA/2J, A/J and $\mathrm{SJL} / \mathrm{J}$ males mice revealed a rank order of sensitivity difference than that observed for cocaine. At KA doses of 25 and $30 \mathrm{mg} / \mathrm{kg}$ the rank order for KA seizure resistance, in order of least to greatest sensitivity, was C57 > A $/ \mathrm{J}>\mathrm{SJL} \geq$ DBA (Table 2). 

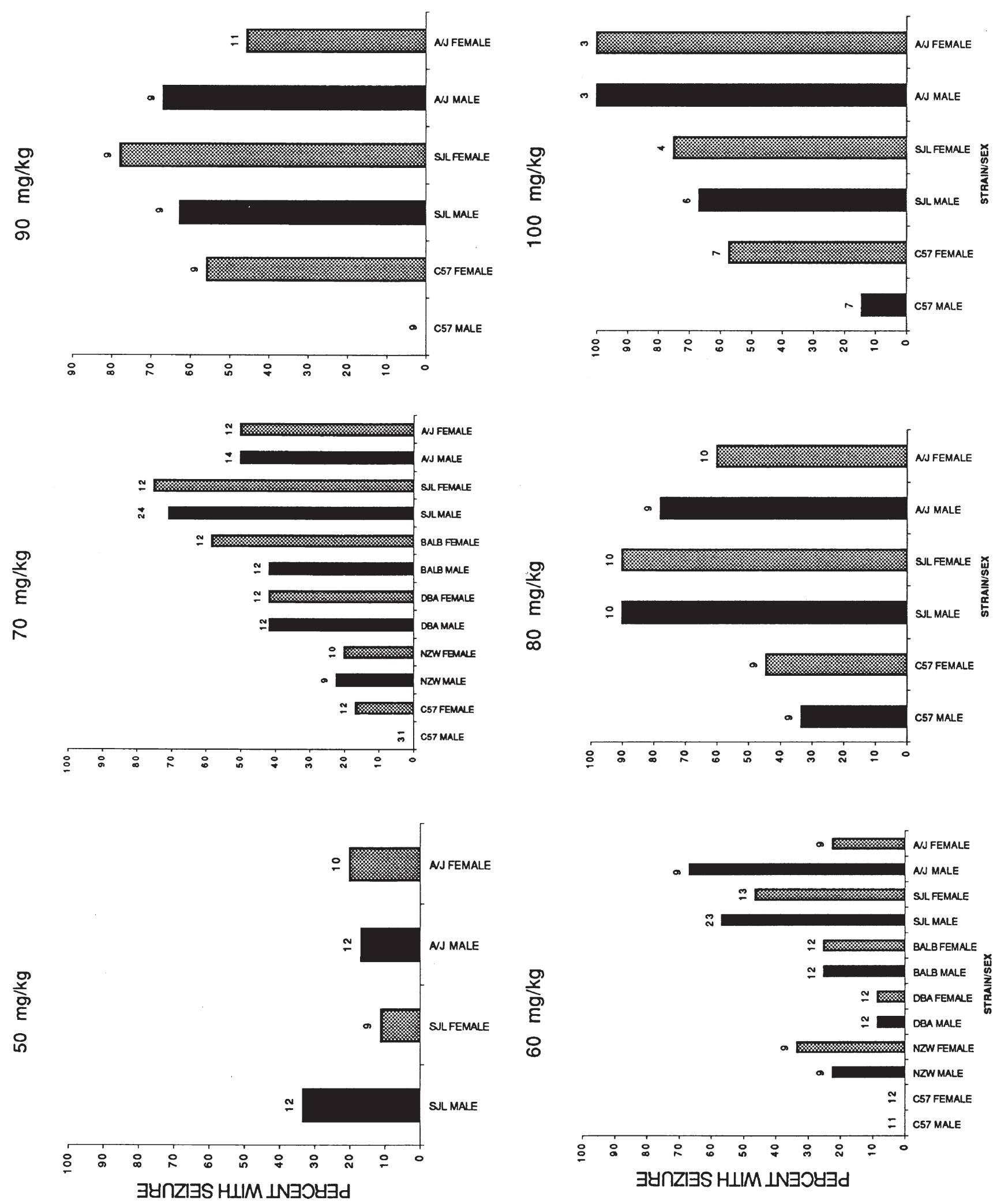

Figure 1. Mouse strain dose response histograms showing the percentage of male (black bar) and female (gray bar) mice demonstrating seizures to an acute cocaine i.p. injection. The number of mice tested at each dose is shown above histogram bars. 
Table 1. Weighted Seizure Severity Score (mean + sd) for C57, SJL and A/J Mice: Dose Response by Gender

\begin{tabular}{|c|c|c|c|c|c|c|}
\hline \multirow[b]{2}{*}{ Strain } & \multirow[b]{2}{*}{ Sex } & \multicolumn{5}{|c|}{ Cocaine Dose } \\
\hline & & $60 \mathrm{mg}$ & $70 \mathrm{mg}$ & $80 \mathrm{mg}$ & $90 \mathrm{mg}$ & $100 \mathrm{mg}$ \\
\hline \multirow[t]{2}{*}{ C57 } & Male & $0(0)$ & $0^{*}+(0)$ & $.7(1.49)$ & $0^{*}+(0)$ & $.4(1.17)$ \\
\hline & Female & $0(0)$ & $.19(.46)$ & $1.1(1.40)$ & $1.3(1.33)$ & $1.3(1.40)$ \\
\hline \multirow[t]{2}{*}{ SJL } & Male & $1.5(1.38)$ & $2.0(1.37)$ & $4.2(2.87)$ & $2.7(2.14)$ & $2.6(2.03)$ \\
\hline & Female & $.95(1.09)$ & $1.8(1.28)$ & $2.5(1.38)$ & $2.2(1.71)$ & $2.6(2.05)$ \\
\hline \multirow[t]{2}{*}{$\mathrm{A} / \mathrm{J}$} & Male & $1.6(1.36)$ & $1.3(1.48)$ & $2.9(2.55)$ & $2.2(2.14)$ & $3.8(1.10)$ \\
\hline & Female & $.63(1.27)$ & $1.5(1.59)$ & $2.3(2.05)$ & $1.7(2.18)$ & 3.5 (1.29) \\
\hline
\end{tabular}

${ }^{*}$ C57 males vs. females $-70 \mathrm{mg}(p=.023), 90 \mathrm{mg}(p=.009)$ weighted seizure severity score

+ C57 males vs. females-70mg (Chi Square $=5.42, p=.019$, Cont Coff $=.34$, Phi $=.36 p=.023), 90 \mathrm{mg}$ (Chi Square $=6.92, p=.0085$, Cont $\mathrm{Coff}=.53, \mathrm{Phi}=.62$ ) number of mice exhibiting seizures

\section{Pharmacokinetic Studies}

No significant differences in cocaine concentrations were evident between the two strains in hippocampus and cerebral cortex at either the 5 or 10-min time point
(Table 3). The cocaine metabolite benzoylecgonine was not detected in any of the samples analyzed. All five A/ $\mathrm{J}$ mice and none of the C57 mice exhibited seizures during the 5-min time period.

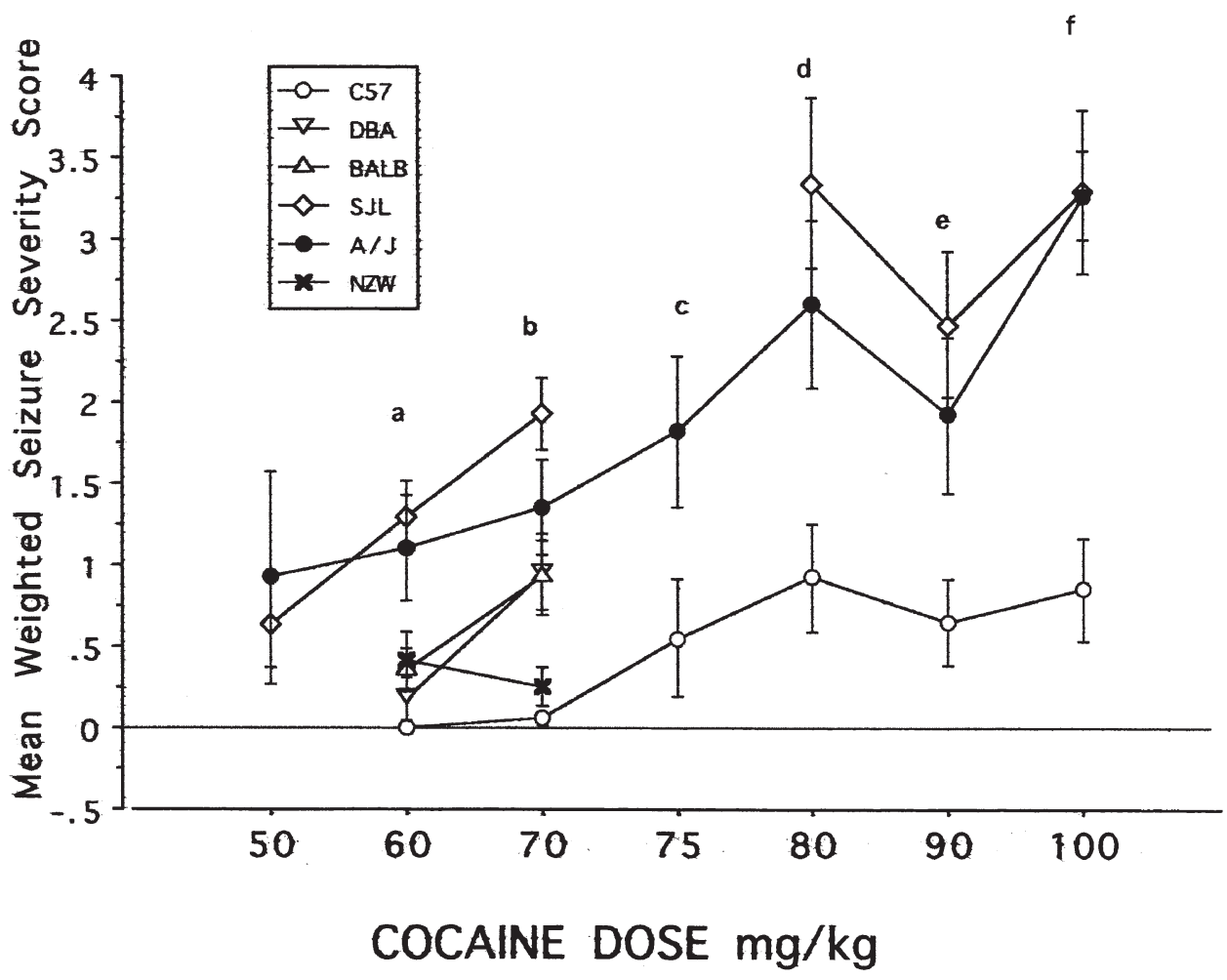

Figure 2. Weighted seizure severity scores mean ( \pm s.e.) for each mouse strain as a function of acute cocaine dose. A 2-factor ANOVA using SRAIN (3) X DOSE (7) was highly significant $(p<.0001)$ for the main effects of COCAINE DOSE and STRAIN (C57, SJL, A/J). Post hoc testing was conducted using the Bonferroini/Dunn multiple comparison procedure: $\mathrm{a}=p<.0001 \mathrm{SJL}$ vs. C57, $p=.002 ; \mathrm{A} / \mathrm{J}$ vs. C57

$\mathrm{b}=p<.0001 \mathrm{~A} / \mathrm{J}$ and SJL vs. C57

$\mathrm{c}=p=.05 \mathrm{~A} / \mathrm{J}$ vs. C57

$\mathrm{d}=p=.0007$ SJL vs. C57; $p=.01 \mathrm{~A} / \mathrm{J}$ vs. $\mathrm{C} 57$

$\mathrm{e}=p=.003$ SJL vs. C57

$\mathrm{f}=p=.002 \mathrm{~A} / \mathrm{J}$ vs. C57. 

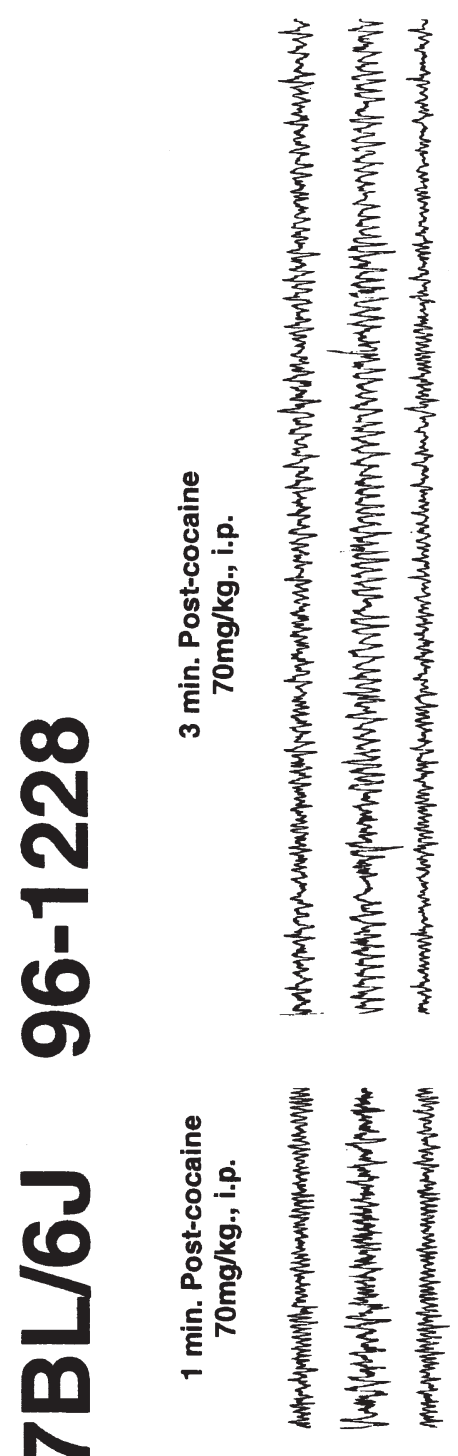

in
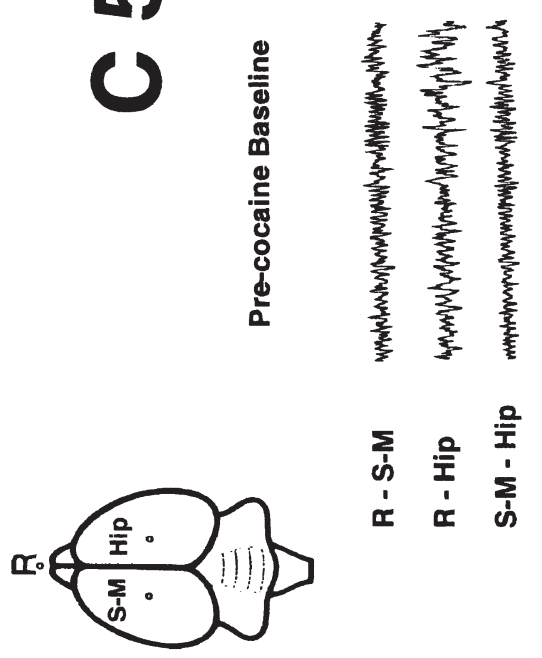

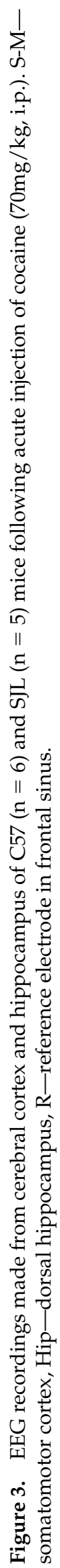


Table 2. Dose/Response Effect of Kainic Acid in Mature C57BL/6J, DBA/2J, A/J and SJL/J Mice ${ }^{1}$

\begin{tabular}{|c|c|c|c|c|c|c|c|c|}
\hline \multirow[b]{2}{*}{ Dose (mg/kg) } & \multicolumn{4}{|c|}{$\begin{array}{c}\text { Number of Mice } \\
\text { Tested }\end{array}$} & \multicolumn{4}{|c|}{$\begin{array}{c}\% \text { with Generalized } \\
\text { Seizures }\end{array}$} \\
\hline & C57 & DBA & $\mathbf{A} / \mathbf{J}$ & SJL & C57 & DBA & $\mathrm{A} / \mathrm{J}$ & SJL \\
\hline 10 & 3 & 3 & 0 & 5 & 0 & 0 & - & 0 \\
\hline 20 & 4 & 5 & 5 & 5 & 0 & 20 & 20 & 60 \\
\hline 25 & 10 & 10 & 5 & 5 & 0 & 80 & 20 & $60^{* *}$ \\
\hline 30 & 4 & 4 & 5 & 5 & 25 & 100 & 40 & $100^{*}$ \\
\hline
\end{tabular}

${ }^{1}$ Mice were injected with kainic acid at the indicated dose and observed for 4 hours to determine behavioral seizure susceptibility, ${ }^{*} p<$ $.03,{ }^{* *} p<.002, \chi^{2}$ Analysis.

\section{DISCUSSION}

A systematic survey of acute cocaine-induced seizure sensitivity was conducted on inbred mouse strains as a prelude to genetic dissection of this complex trait. A range of strain-specific sensitivities was documented with C57 mice being most resistant and SJL and A/J mice most sensitive. This characterization is based both on population seizure frequency experiments as well as on estimation of individual seizure severity using a broad-based seizure score. Pharmacokinetic studies indicate that differences between $\mathrm{C} 57$ and $\mathrm{A} / \mathrm{J}$ mice are not explained by a differential rate of absorption or metabolism of cocaine. Previous studies of C57 and DBA mice also failed to show strain differences in brain cocaine levels after acute injection (Jones et al. 1993). Previous systematic studies on genetic factors that influence cocaine-related seizures have been reported but are limited (DeFiebre et al. 1989; Marley et al. 1991a, 1991b; George 1991b). Most notably, the results and conclusions from our strain analysis conflict with those of Marley (Marley et al. 1991a) who found that C57 mice are the most sensitive to acute cocaine-induced seizures whereas SJL mice are the most resistant with DBA and BALB mice being intermediate. A/J mice were not included in that study (Marley et al. 1991a). These apparently opposite sets of results raise concerns regarding evaluation of acute cocaine seizure phenotypes.

Table 3. Cocaine concentrations ${ }^{1}$ in Hippocampus and Cerebral Cortex from Male A/J and C57BL/6J Mice ${ }^{2}$

\begin{tabular}{lrrrrr}
\hline & \multicolumn{2}{c}{$\mathbf{A} / \mathbf{J}$} & & \multicolumn{2}{c}{ C57BL/6 J } \\
\cline { 2 - 3 } \cline { 6 - 6 } Brain Region & 2 Min & 5 Min & & 2 Min & 5 Min \\
\hline Hippocampus & 9.5 & 28.5 & & 10.0 & 24.1 \\
& $(1.3)$ & $(6.2)$ & & $(5.3)$ & $(5.1)$ \\
Cortex & 12.2 & 25.0 & & 13.5 & 24.1 \\
& $(0.4)$ & $(4.6)$ & & $(4.7)$ & $(5.0)$ \\
\hline
\end{tabular}

\footnotetext{
${ }^{1}$ Values are Mean (+S.E.) and are given in $(\mu \mathrm{g} / \mathrm{g}$ protein $)$

${ }^{2}$ Groups of mice ( $n=5 /$ strain/time point) injected with cocaine $(70 \mathrm{mg} /$ $\mathrm{kg}$, ip) and killed at 2 and $5 \mathrm{~min}$. post injection
}

In the present study, electrographic correlates of behavioral effects of cocaine were investigated in both C57, A/J and SJL mice. C57 mice were never observed to exhibit abnormal electrical discharges characteristic of seizure activity whereas behavioral seizure activity in SJL and A/J was always associated with EEG spiking. These results are consistent with a large body of literature documenting that $\mathrm{C} 57$ mice are unique in their relatively high degree of resistance to many types of experimental seizures (Schlesinger et al. 1968; Deckard et al. 1976; Kellogg 1976; Engstrom and Woodbury 1988; Kosobud and Crabbe 1990; Ferraro et al. 1995a, 1998). The study by Marley (Marley et al. 1991a) relied solely upon behavioral observation for evaluation of seizure activity and it is possible that motor dysfunction such as ataxia or other involuntary movements, which we observed in cocaine-treated C57 mice, were scored as seizures. In our studies the presence or absence of behavioral seizures was corroborated by using EEG recordings. Measurement of EEG is considered by most to be the gold standard for seizure detection. Marley (Marley et al. 1991a) did not record EEG activity from any of the strains used in his study (personal communication). Another potentially significant experimental difference between the present study and that of Marley (Marley et al. 1991a) relates to housing conditions for mice. In the latter study, all mice were group housed until the time of seizure testing (Marley et al. 1991a) whereas in the present study, mice were housed individually for one week before the time of testing. Since SJL males exhibit highly aggressive behavior, it is likely that in grouphousing conditions these mice would be exposed to a relatively stressful home cage environment. Thus, the ability of stress to increase seizure threshold (Oliverio et al. 1983) may have contributed to the relative resistance of SJL mice noted by Marley (Marley et al. 1991a). While differences in housing (single vs group) conditions prior to testing might account for the differences observed by Marley (Marley et al. 1991a) and the present study, this can not be determined without further investigation. All other conditions in our study were similar to Marley's (Marley et al. 1991a) study. In both studies mice were obtained from the same supplier (Jackson Laboratory); mice were removed from their home cages and tested in novel test environment (conditioned for 30 minutes) at the same time of day; mice were the same age (Marley study, 55-70 days, present study, 49-77 days). In general, differences in housing conditions and seizure evaluations between the present study and that of Marley (Marley et al. 1991a) hinder direct comparison results.

Results of our study also document an influence of sex on acute cocaine-related seizure susceptibility; however, of the four strains studied, only C57 mice exhibited this trait with females significantly more sensitive than males. This is consistent with the fact that female C57 mice have a significantly lower maximal electroshock 
threshold compared to males (Ferraro et al. 1998). Other strains were characterized by equivalent sensitivities for the two sexes although for $\mathrm{A} / \mathrm{J}$ and SJL mice there was a trend for increased sensitivity among males. In rats, prenatal cocaine exposure results in differential sex effects on seizure sensitivity in adulthood with males more susceptible to cocaine kindling and females more susceptible to acute cocaine-induced seizures (Snyder-Keller and Keller 1995). Reproductive hormones appear to cause cocaine to have greater behavioral effects on females than on males in both acute and long-term abuse (van Haaren et al. 1990). In humans, female cocaine users have been found to experience cocaine-related seizures at a rate three times greater than male cocaine users, a difference not explained by ethnicity, cocaine dose, or route of administration (Dhuna et al. 1991). Additionally, greater numbers of women experience a seizure with their first cocaine usage compared to men (Dhuna and Pascual-Leone 1990). Apart from seizures, a number of other cocaine-related effects have been observed to occur in a sex-specific manner as well (Morse et al. 1993, 1995; Kelley and Middaugh 1996; Xu et al. 1997). The activities of cocaine metabolizing enzymes are also documented to exhibit significant sex-specific differences (Leibman et al. 1990). Overall, the potential for cocaine to have sex-specific effects reflect the complexity of the mechanisms influencing pharmacological responses and emphasizes the need for careful phenotypic evaluations.

In order to evaluate the possibility that susceptibility to cocaine may be a more general phenomenon related to overall seizure predisposition rather than to a specific action of cocaine, strain sensitivities to kainic acid (KA) induced seizures were compared with sensitivities to cocaine-induced seizures. Confirming several literature reports for sensitivity to KA seizures (Engstrom and Woodbury 1988; Ferraro et al. 1995a, 1997), results showed that DBA mice were most sensitive whereas C57 mice were most resistant. A/J mice were more like C57 whereas SJL mice were more like DBA. The lack of correlation between strain responses to KA and cocaine suggests that the molecular substrates underlying sensitivity to the seizure-inducing effects of these drugs are not identical. Thus, although quantitative trait loci mapping studies have begun to localize genes that influence response in KA seizure (Ferraro et al. 1997) and other conventional seizure paradigms, it is likely that QTL mapping for acute cocaine seizures in crosses between C57 and A/J or SJL will provide novel information relevant to the pharmacology of cocaine.

In summary, results of this study document substantial strain variation in susceptibility to seizures induced by acute high doses of cocaine. C57 mice were observed to be the most resistant with $\mathrm{A} / \mathrm{J}$ and SJL mice equally the most susceptible. These differences are not associated with brain cocaine levels and cannot be explained by a general strain-specific predisposition to seizures. Estima- tion of the relative influence of genetic and environmental factors in this model will determine the feasibility of using QTL strategies to identify specific genetic components of the response. Successful genetic dissection of this complex trait will provide a better understanding of the action of cocaine in the brain and will yield important information directly relevant to cocaine toxicity.

\section{ACKNOWLEDGMENTS}

This work was supported by a Department of Veterans Affairs Merit Review Award. We acknowledge the technical contributions of Michelle Laibinis, Felix A. Grau and Andrew Henry.

\section{REFERENCES}

Alldredge BK, Lowenstein DH, Simon RP (1989): Seizures associated with recreational drug abuse. Neurology 39:1037-1039

Anderson VE, Rich SS, Hauser WA, Wilcox KJ (1991): Family studies of epilepsy. Epilep Res Suppl 4:89-103

Choy-Kwong M, Lipton RB (1989): Seizures in hospitalized cocaine users. Neurology 39:425-427

Deckard BS, Schlesinger K, DeFries JC (1976): Developmental patterns of seizure susceptibility in inbred strains of mice. Dev Psychobiol 9: 17-24

DeFiebre CM, Ruth JA, Collins AC (1989): Differential sensitivity of long-sleep and short-sleep mice to high doses of cocaine. Pharmacol Biochem Behav 34:887-893

Derlet RW, Albertson TE (1989a): Diazepam in the prevention of seizures and death in cocaine-intoxicated rats. Ann Emergency Med 18:542-545

Derlet RW, Albertson TE (1989b): Emergency department presentation of cocaine intoxication. Ann Emerg Med 18:182-186

Dhuna A, Pascual-Leone A (1990): New onset seizures after first-time cocaine abuse. Epilepsia 31:605-606

Dhuna A, Pascual-Leone A, Langendorf F, Anderson DC (1991): Epileptogenic properties of cocaine in humans. Neuro Toxicology 12:621-626

Engstrom FL, Woodbury DM (1988): Seizure susceptibility in DBA and C57 mice: the effects of various convulsants. Epilepsia 29:389-395

Ernst AA, Sanders WM (1989): Unexpected cocaine intoxication presenting as seizures in children. Ann Emerg Med 18:774-777

Ferraro TN, Smith GG, Berrettini WH, Golden GT (1993): Differential sensitivity to kainic acid-induced seizures in mature C57BL/6J and DBA/2J mice. Neurosci Abst 19:390

Ferraro TN, Golden GT, Smith GG, Berrettini WH (1995a): Differential susceptibility to seizures induced by systemic kainic acid in mature DBA/2J and C57BL/6J mice. Epilepsia 36:301-307

Ferraro TN, Golden GT, Ballas C, Smith GG, Schork N, Berrettini WH (1995b): Kainic acid-induced seizures in inbred mice: quantitative trait loci (QTL) mapping. Neurosci Abstr 21:980 
Ferraro TN, Golden GT, Smith GS, Ballas C, Choi H, Schork NJ, St Jean P, Berrettini WH (1997): Mapping murine loci for seizure responses to kainic acid. Mammalian Genome 8:200-208

Ferraro TN, Golden GT, Snyder R, Laibinis M, Smith GG, Buono RJ, Berrettini WH (1998): Genetic influences on electrical seizure threshold. Brain Res 813:207-210

Frankel WN, Johnson EW, Lutz CM (1995b): Congenic strains reveal effects of the epilepsy quantitative trait Locus, E12, separate from other E1 loci. Mamm Genome 6:839-843

George FR (1991b): Cocaine toxicity: genetic evidence suggests different mechanisms for cocaine-induced seizures and lethality. Psychopharmacology 104:307-311

Golden GT, Smith GG, Ferraro TN, Reyes PF, Kulp JK, Fariello RG (1991): Strain differences in convulsive response to the excitotoxin kainic acid. NeuroReport 2:141-144

Golden GT, Smith GG, Ferraro TN, Reyes PF (1995): Rat strain and age differences in kainic acid induced seizures. Epilepsy Res 20:151-159

Golden GT, Krishna NK, Smith GG, Reyes PF, Ferraro TN (1994): Kainic acid-induced seizures in rats: Does route of administration make a difference. Neurosci Abst 20:1453

Greenberg DA, Durner M, Delgado-Escueta AV (1992): Evidence for multiple gene loci in the expression of the common generalized epilepsies. Neurol 42:56-62

Holland RW, Marx JA, Earnest MP, Ranniger S (1992): Grand mal seizures temporally related to cocaine use: Clinical and diagnostic features. Annals of Emergency Medicine 21:772/9-776/13

Javaid JI, Dekirmenjian H, Davis JM, Schuster CR (1978): Determination of cocaine in human urine, plasma and red blood cells by gas-liquid chromatography. J Chromatography 152:105-113

Jobe PC, Picchioni AL, Chin L (1973): Role of brain norepinephrine on audiogenic seizure in the rat. J Pharmacol Exp Ther 184:1-10

Jones BC, Reed CL, Radcliff RA, Erwin G (1993): Pharmacogenetics of cocaine: 1 . locomotor activity and self-selection. Pharmacogenetics 3:182-188

Jonosson S, O’Meara M, Young JB (1983): Acute cocaine poisoning: importance of treating seizures and acidosis. Am J Med 75:1061-1064

Kelley BM, Middaugh LD (1996): Ethanol self-administration and motor deficits in adult C57BL/6J mice exposed prenatally to cocaine. Pharmacol Biochem Behav 55:575-584

Kellogg C (1976): Audiogenic seizures: relation to age and mechanisms of onoamine neurotransmissions. Brain Res 106:87-103

Kosobud AE, Crabbe JC (1990): Genetic correlations among inbred strain sensitivities to convulsions induced by nine convulsant drugs. Brain Res 526:8-16

Kosobud AE, Cross SJ, Crabbe JC (1992): Neural sensitivity to pentylenetetrazol convulsions in inbred and selectively bred mice. Brain Res 592:122-128

Leibman D, Smolen A, Smolen TN (1990): Strain, sex and developmental profiles of cocaine metabolizing enzymes in mice. Pharmacol Biochem Behav 37:161-165

Leppert M, Anderson VE, White R (1991): The discovery of epilepsy genes by genetic linkage. Res Suppl 4:181-188

Marley RJ, Witkin JM, Goldber SR (1991a): Genetic factors influence changes in sensitivity to the convulsant properties of cocaine following chronic treatment. Brain Research 542:1-7

Marley RJ, Witkin JM, Goldberg SR (1991b): A pharmacogenetic evaluation of the role of local anesthetic actions in the cocaine kindling process. Brain Research 562:251-257

Morse AC, Erwin VG, Jones BC (1993): Strain and housing affect cocaine self-selection and open-field locomotor activity in mice. Pharmacol Biochem Behav. 45:905-912

Morse AC, Erwin VG, Jones BC (1995): Behavioral responses to low doses of cocaine are affected by genetics and experimental history. Physiol \& Behav 58:891-7

Myers JA, Earnest MP (1984): Generalized seizures and cocaine abuse. Neurology 34:675-676

Ogunyemi AO, Locke GE, Kramer LD, Nelson L (1989): Complex partial status epilepticus provoked by "crack" cocaine. Ann Neurol 26:785-786

Oliverio A, Castellano C, Puglisi-Allegra S (1983): Anticonvulsant effects of stress: role of endogenous opiods. Brain Res 271:193-195

Park A (1997): Addicted to a brain chemical called dopamine. Time 150:69-76

Patrick KS, Boggan WO, Miller SR, Middaugh LD (1993): Gas chromatographic-mass spectrometric determination of plasma and brain cocaine in mice. J Chromatography 621:89-94

Schlesinger K, Boggan WO, Griek BJ (1968): Pharmacogenetic correlates of pentylenetetrazole and electroconvulsive seizure thresholds in mice. Psychopharmacol. (Berl) 13:181-188

Schwartz RH (1989): Seizures associated with smoking 'crack' - a survey of adolescent 'crack' smokers. West J Med 150(2):213

Seyfried TN, Glaser GH (1985): A review of mouse mutants as genetic models of epilepsy. Epilepsia 26:143-150

Snyder-Keller AM, Keller Jr RW (1995): Prenatal cocaine alters later sensitivity to cocaine-induced seizures. Neurosci Let 191:149-152

Taylor BA (1976): Genetic analysis of susceptibility to isoniazid-induced seizures in mice. Genet 83:373-377

Tseng CC, Derlet RW, Albertson TE (1992): Cocaine-induced respiratory depression and seizures are synergistic mechanisms of cocaine-induced death in rats. Annals of Emergency Medicine 21:486/15-493/22

van Haaren F, van Hest A, van Hattum T (1990): Behavioral differences between male and female rats: Effects of gonadal hormones on learning and memory. Neurosci Biobehav Rev 14:23-33

Washton AM, Tatarsky A (1983): Adverse effects of cocaine abuse. Problems of Drug Dependence, NIDA Research Monographs Series 49, US Dept of Health and Human Services, pp 247-254

Weissbecker KA, Durner M, Janz D, Scaramelli A, Sparkes RS, Spence MA (1991): Confirmation of linkage between juvenile myoclonic epilepsy locus and the HLA region on chromosome 6. Am J Hum Genet 38:32-36

Xu W, Bai F, Tummalapalli CM, Miller DD, Middaugh L, Boggan WO (1997): the interactive effects of cocaine/gender on immune function in mice. An observation of in vivo acute cocaine exposure. Internat J Immunopharmac 19:333-340 